\title{
The Nexus of Professional Service Practices in Chinese Financial Centres
}

\author{
Andrew Jones \\ Centre for Professional Service Firms \\ Cass Business School \\ City, University of London \\ Northampton Square \\ LONDON EC1V 0HB \\ UK \\ email.: andrew.jones@city.ac.uk \\ tel. +44 (0) 2070403123
}




\begin{abstract}
Bringing together work within economic geography and regional science, this paper argues that to develop a more sophisticated theoretical understanding of how of international financial centres (IFCs) are evolving, an approach which conceptualises the nexus of midlevel economic practices within and between professional service firms and sectors has considerable merit. Drawing upon theoretical work on relationality and place, it argues that the IFC as a place is instrumental in shaping a nexus of professional service practices that produce particular economic outcomes. It develops this argument by presenting research into professional service industries in two Chinese IFCs - Hong Kong and Beijing.
\end{abstract}

Keywords: professional services; China, global cities, finance; Hong Kong; Beijing 


\section{1) Introduction}

Research into professional and business services has established a detailed understanding of how a multitude of different business service industries spanning finance, legal services, consultancy, advertising and marketing, software (Illeris, 1996; Wood 2005; Hall et al 2009; Daniels 2012) - to name just a few - are at the centre of successful economic activity within International Financial Centres (IFCs) and global city networks more generally. Much work has sought to understand the relationships between different cities and city-regions within global city networks, building on several decades of urban theory that seeks to understand the relative importance of different city regions in an increasingly globalized economy (c.f. Sassen 2002; 2006; Ancien 2013). Business and professional service industries are used as an indicator of a city-region's position in a relational network of global city regions (Taylor et al 2012; 2014; Parnreiter 2014), supporting the integration of global financial markets and the increasingly complexity of public and private sector finance in today’s global economy (French et al 2009; Wójcik 2013a). Key IFCs are thus seen as fulfilling distinctive functions within global city networks (Faulconbridge et al 2007; Cassis and Collier 2009; Walther et al 2011), and as to some extent specialising in certain types of professional and business service provision.

However, the urban and regional science literature identifies a number of limitations with respect to the degree to which the nature and role of professional and business service sector is being effectively theorised within IFCs. Whilst analyses of world/ global cities have moved beyond simplistic hierarchical conceptions to conceptualise the world city archipelago (WCA) (and within that IFCs) in relational terms (Sigler 2013; Smith 2014), there has been a growing call to focus on the socio-spatial practices occurring within global cities and IFCs in order to better understand how specific city-regions are entwined in the operation of the global economy (Van Meeteren and Bassens 2016). A particular focus of this argument is to seek to supersede the concept of the world city network with an emphasis on the WCA as 'a socio-spatial structure with emergent properties', with a necessary empirical emphasis on the economic practices related to professional and business services in order to understand the nature of the production of these relational places.

This represents the entry-point for this paper in both theoretical and empirical terms. It seeks to further develop the argument that a better understanding of both the nature of specific IFCs and how they fit as places into the wider WCA requires a conceptual and empirical focus on the nature of economic practices centred on those places along with the key actors involved - namely professional service firms. Using a practice-oriented approach 
(c.f. Jones \& Murphy 2011) to build on the insights of the work on relational cities and the socio-spatial structure of the WCA, it contends that the significance of place - and the way in which the specific characteristics of place shape economic practice - needs to be given greater weight. It suggests that greater insight into the development of specific IFCs, and their place in the WCA archipelago, can be gained by theorising the way in which both distanciated and place-based relationships intersect to shape the nature of economic practices and outcomes within given IFCs. It seeks to conceptualise how this occurs through the concept of a nexus of professional service practices that are hosted by, but not existentially confined to, specific IFCs. The aim is to move beyond concepts of place-based clustering to better understand how proximate and distant actors are simultaneously enrolled in key practices within places to shape how economic outcomes emerged, and key economic institutions are reproduced and evolve. The approach also draws on Massey's (2005) concept of 'throwntogetherness' to develop theoretical insight into how the nexus of practice in a given IFC is also shaped by place-specific but contingent factors that themselves are 'perforated' by translocal relations.

The paper develops these arguments by presenting research into the professional service practice nexus in two Chinese IFCs - Hong Kong and Beijing- that are the focus of significant attention as key IFCs in the current rebalancing of activity in the global economy. Building on work that has already sought to conceptualise the differential roles and specific characteristics of these two IFCs, the paper illustrates how theories of IFC development might become more sophisticated at understanding the dynamic factors that shape the nature of IFCs and their likely paths of future development. It does this through an empirical analysis that identifies sets of key 'mid-level' economic practices which underpin the distinctive role of each of these IFCs, but which also are bound into distanciated relationships that themselves escape the confines of the IFC as a place. Through analysis of the professional service practice nexus in Hong Kong, the research suggests that the IFC behaves not only as an offshore centre in China (c.f Lai 2012), but also fulfils an important transgressive 'gateway role' as an IFC serving the Chinese economy. In contrast, the practice nexus approach reveals how Beijing's role as a political and regulatory IFC is underpinned by distinctive innovation and local labour market formations. In both cases, it moves theoretical understanding of the distinctiveness of these IFCs beyond a conceptualisation that bases their interrelations as being purely associated with attributes contained or confined within one city or the other.

The paper develops these arguments in a series of stages. The next section begins by outlining how the existing literature on IFCs is increasingly critical of hierarchical and 
network-based conceptions of world cities and IFCs, moving moved towards a relational conceptualisation that has become increasingly concerned with the socio-spatial approach to understanding IFC development. Paying particular attention to work that has focused on Chinese IFCs (and especially Hong Kong and Beijing), it also considers the way in which understandings of professional services industries are being incorporated into this more recent approach. The third part of the paper outlines how this theoretical debate around IFC development might be advanced with an approach that foregrounds the nature of professional service practices within and between places further. It outlines the concept of the practice nexus as a means to conceptualise the intersection of proximate and distant relations with the 'throwntogetherness' of IFCs as distinct places. It seeks to demonstrate how the lens of the professional service practice nexus generates new insights into the interplay of near and distant relationship across a range of actors which shape economic outcomes and longer terms development trajectories within IFCs. The fourth part then deploys these arguments in relation to the two empirical Chinese case study IFCs: Hong Kong and Beijing. The research into professional service practices presented enables a theorization that moves beyond the relatively static accounts of the distinctiveness of each IFC and provides a basis for understanding the mid-level practices that underpin their relational position in the WCA and shape the evolution of their distinctiveness as places. Finally, the paper ends by drawing together some summary arguments about the utility of a practice nexus approach for developing more sophisticated theories of IFC distinctiveness across the global economic system.

\section{2) World cities, IFCs and professional service practices}

The existing literature on IFCs and global city regions spans a range of disciplines including urban studies, economic geography, sociology and regional science. However, over the last couple of decades it has been increasingly dominated by at least three major, and interconnected, threads of theoretical and empirical work centred around cities as the location of professional and business service activity in the global economy, their relative importance vis-à-vis each other and as the location of power.

It is important here to chart the major trajectory which this debate has taken. Broadly, since the 1980s the role of cities as national centres of finance has shifted to their significance in an integrating global economy. John Friedmann (1986)'s well-cited 'world city hypothesis' linked urban development to global economic processes and, in particular, the role of 
financial and other specialised professional services. Saskia Sassen (1991) of course further developed this idea in her 'global city' theorisation, which saw certain key global cities (London, New York and Tokyo) as existing at the top of a global urban hierarchy because of their specialist role as the location for key advanced financial and business (producer) services. The global city concept became widely adopted during the 1990s and integrated with the ideas of Manuel Castells' (c.f. Castells 1996; 2001) and others on the emergence of a 'global network society'. Thus, a substantial literature has sought to both identify and map the relationships between global cities in network terms, using primary research and secondary empirical data to conceptualise the significance of various cities in different hierarchies of places for certain economic activities or industries. At the forefront of such work is the Globalization and World Cities (GaWC) approach, for example, using professional service firm transaction datasets to develop initially both hierarchies and network maps of hundreds of cities around the globe (Taylor 2005; Taylor et al 2012).

However, in the last decade this debate has moved on from simplistic conceptions of global city hierarchies and the concept of the network. Several important threads mark the current state of this debate. First, initial hierarchical ideas of a global system of world cities have been displaced with a more sophisticated view of a world city network or (more recently) archipelago (WCA) that was heavily-informed by Castell's notion of the 'space of flows'. Sassen herself has reoriented her theoretical arguments to see the global city as a process operating unevenly through the space of flows, with command and control functions distributed in a complex landscape through the global urban system. The GaWC approach added to this by providing detailed analysis of the empirical complexity of industry relationships between different global cities, creating the scope to understand the nature of types of specialization by different cities across the global urban system. In particular, the WCA approach has sought to differentiate between the wider metageography of world cities and a more specific ‘backbone of IFCs’ (c.f. Bassens \& Van Meetern 2016).

Second, and furthermore, the concept of the network itself as applied to global / world cities or IFCs has come under critical scrutiny. Recent contributors have moved the world city analysis approach towards a post-network epistemological paradigm. Notably, this literature argues it is 'overly reductionist to collapse the more extensive geography of the WCA onto the concise network of the IFCs' (Bassens \& Van Meeteren: 67) because although all IFCs are world cities, 'the WCA does extend greatly beyond that shortlist'. The latter is because professional service practices ‘related to the worlds of finance and production' have 'become increasingly interdependent' in a way that means they are hard to contain or reduce 
to practices occurring exclusively within IFCs. This latter argument is in many respects echoed in the extensive economic geographical literature on clusters in its application to IFCs and professional service firms (Keeble \& Nachum 2002; Isaksen 2004; Faulconbridge 2007; Wójcik \& James 2015). A considerable literature has examined the nature of financial and business service clusters within IFCs but more recently has also sought to problematize the balance between local spillover effects and the translocal connections of finance and business services (e.g. Faulconbridge 2008). This work has thus begun to focus attention in the tensions within a local embeddedness / global pipelines perspective on the key industries within IFCs (c.f. Bathelt et al 2004).

Third, and following on from this, recent work poses a direct challenge to the idea that command and control (or the exercise of power in the global economy) can in any meaningful way be understood as being produced in specific IFCs in the way Sassen originally expressed and the WCA literature has sought to conceptualise through its network metaphor. Power exists in and across the social, material and institutional spaces of IFCs and the wider WCA, but is not easily reduced to residing within these spaces. The consequence of this is an argument to reconceptualize of the nature of power in WCA space. It requires a shift of epistemological concern onto actors and their practices that underpin power relationships, and in particular how they are configured spatially. Such work proposes a variety of spatial conceptualisations of power to try to better understand where power in the global urban system resides, which actors are able to wield it, and how that is constituted across different types of spaces (social, material organizational and so on). Professional (or advanced producer) service practices become a particular focus in this undertaking as the key practices that constitute the exercise of power through the WCA.

Thus, a number of unresolved tensions exist within the current literature with respect to these theoretical debates. First, in moving away from concepts of the network and / or localised cluster (at the firm and sector level), the relational nature of professional service activity is being conceptualized as existing both within and between IFCs. Whilst a more sophisticated theoretical basis to understand where economic activity occurs, there are limitations in the vagueness of this framing. Is local more significant than translocal and how does the location (or betweenness) of activity bear on economic outcomes? Second, if that tension exists at the scale of the firm, then it also applies to conceptions of the IFC itself as a city place counterposed against the importance of distant relationships. Relationality frames the nature of a given IFC in both its place-based characteristics and also how its relations with other cities are constituted. The nature and significance of agency in this is, however, 
opaque. Cities (as we shall see) are argued to fulfil specific functions versus other cities Beijing as a political or regulatory hub versus Hong Kong as an offshore centre (Lai 2012) but the relative agency of the city as a place versus firms or entities that exist through those places is unclear. What balance of actors in different locations are (re)producing that IFC distinctiveness?

The goal of this paper is to intervene constructively in this theoretical arc by arguing that a relational conception of IFCs and city-regions can address these challenges through a practice-oriented approach that benefits from drawing in insights into the relational nature of place elsewhere in human geography. Before turning to theories of practice, it is important to understand what this additional insight to the relational WCA perspective corresponds to. I want to draw on two elements to relational concepts of place that have not been widely integrated to date: arguments about 'relational place making' (Pierce et al 2011; Murphy 2011; Celatta \& Coletti 2014) and Massey's relational understanding of how relations come together in places through the concept of 'throwntogetherness' (which the former literature also draws upon).

Regarding 'relational place-marking', key are recent arguments concerned with exactly how to conceptualise the multi-scalar nature of places in relational terms. Pierce et al (2011) suggest that a rich, multi-scalar sense of place offers 'a compatible theoretical tool' which is something that 'extends networks by always grounding them in multiple, interconnected, multi-scalar and overlapping places (ibid.: 55)' They therefore point out that relationality, in this view, is always grounded, fixed and territorially embedded (Malpass et al. 2007; Jones, M. 2009; Darling 2010;). Contesting the preference of the social science literature to understand places as 'local', they follow Amin's (2004) application of this to city-regions 'perforated' by globalization in arguing that they can be 'recast as nodes that gather flow and juxtapose diversity, as places of overlapping - but not necessarily locally connected - relational networks, as perforated entities ... [that] come with no automatic promise of territorial or systemic integrity.' (2004, 34). Places in this sense can be understood (after Massey 2004; 2005) as 'bundles' of space-time trajectories drawn together by individuals through cognitive and emotional processes’ $(2005,119)$ and which are a 'manifestation of the condition of 'throwntogetherness', a haphazard social and physical propinquity $(2005,140)$ '. In this argument, individual bundles 'make' places by 'referencing and reconfiguring the many simultaneous places that they participate in’ (Pierce et al 2011: 58). This aligns with Harvey's (1996) notion of place-making as 'carving out of 'temporary permanences' from spaces (1996: 241) in a way that see the process of place-making as an 
iterative, evolutionary process of defining not just boundaries or territories, but the rules and norms against which socio-spatial practices are understood (Pierce et al 2011: 58). This relational conception of place recasts the ‘city -region’ or IFC as no longer discrete physical territories but as an interlocking bricolage of relationships.

Whilst these theories relational place-making and 'throwntogetherness' are grounded in socio-cultural and political objects of study, I argue that they have considerable utility in seeking to better theorise the nature of IFCs and city-regions.

There are three propositions developed in this paper in that respect. First, the relational WCA literature has yet to succeed in unpacking the basis for the relative significance or importance of a given world city IFC. A move beyond the network or hierarchy idea has been established, but how the complex interaction of local and translocal relations constitute IFC distinctiveness is not clearly specified or well understood. Second, and related, there remains considerable tension and ambiguity in theorising the degree to which translocality perforates (in Amin's terms) the world city as a place, and how that is important. That it is (increasingly) important is now well-established, but simply identifying the existence of perforating translocal relationships is insufficient to reconcile their role in the production of place. Finally, there has not been sophisticated attempt to engage in the complex array of contextual relations that are not directly attributable to the location of key firm clusters or institutional environments but which still are important in (re)producing a given world city. Understanding the relational nature of the wider world city context - with its array of local and translocal relations beyond immediate economic actors, - is also important to better conceptualise the distinctive nature and evolution of IFCs and world cities.

In the next part of this paper, an approach which deploys a practice-oriented focus on the nature of professional service activity is argued to be a powerful tool to seek to move the debate forwards productively in relation to these propositions.

\section{Retheorising IFC distinctiveness: a professional service 'practice nexus' approach}

Within economic geography over the last decade there has been growing interest in a broad 'practice-oriented' approach as an epistemological and methodological tool that places economic practices as the central object of study in seeking to better understanding the nature and spatiality of economic activity (Jones \& Murphy 2011; Jones 2013). Whilst representing a diverse body of empirical research, a shared focus exists within this literature on identifying 
key economic practices that shape the nature of economic outcomes in the space economy. Whilst all of the social world is reproduced through a myriad of social practices, the goal of this approach is to identify a relatively small number of key practices that have most influence on economic outcomes - whether that be at the firm, sector or city-region level (c.f. Jones \& Murphy 2011). This framework draws on a variety of sociological theorisations of social practice that seek to identify mid-level concepts of practices in specific contexts that represent 'demi-regularities' that both endure over time and occupy distinct spaces (ibid.). In so doing it draws on work that seeks to theorise the contrasting nature and scale of various practices, captured in Schatzki's (2002) differentiation between praxis and practice: the former referring to actual activity whereas the latter seeking to capture the routines that shape practice (see also Cettina et al 2005). Whilst this binary division is problematic insofar as it risks dividing intertwined forms, it is also useful in framing the scale and duration of different forms of key practices. The goal is to develop 'mid-level' theorisation that bridges the micro/macro divide which continues to be the subject of considerable debate within economic geography, regional science and the social sciences more generally

In this paper, the application of this approach is to the nature of professional service practices within three key professional service industries at the heart of IFC activity: finance, legal services and strategy consultancy services. In developing a practice-oriented approach in relation to professional service practices, the theoretical contribution here also draws upon recent practice-oriented work concerned with IFC development and the linkages between urban and regional science and organizational studies. The next step is to outline how this work informs a theoretical framework for understanding professional service practices within an IFC before proposing the concept of the practice nexus as a means of integrating theories of practice within those of IFCs or world cities as relational places.

\subsection{Conceptualising professional service practices}

A growing body of research has examined different professional service practices within a diverse set of sectors including investment banking, venture capital, legal services, architecture and strategy consultancy. The 'practice-shift' (cf. Jones 2013) in relation to professional services has therefore developed a significant body of work, but only recently has there been a more direct engagement with the literature on IFCs and the WCA. In particular, at least four strands to this work are an important basis for the approach development here. 
First, a significant body of work has focused on management decision-making practices within professional services, analysing empirically the specific practices of key senior managers or groups of managers (Faulconbridge 2006; Hall 2006; 2007; Cook et al 2012). The major focus of this work is, in Schatzki’s terms, praxis rather than practice at the level of routinized action. Research has examined how senior managers make investment decisions, wield power and develop organizational strategy (Strom 2013; Jones \& Search 2013). There is thus also an impetus to examine the key practices within organizations below top management in relation to the second layer of organizational operational. A good example is Meyer's (2015; 2016) work into the practices of managers in sovereign debt funds and those leading trading strategies in financial firms. This research has also examined how the success and failure of firms and sectors is the outcome of a key actors located across a global network of IFCs. Faulconbridge (2008), for example, examines the nature of the impact of these networks on the organizational culture of global law firms.

A second strand of work has begun to examine the spatial context and spatiality of decision-making practices. In this respect, research on professional service practices has examined how practices are institutionally-embedded in specific contexts. A focus is how firm-level practices are entwined with external institutions, both being shaped by and shaping the institutional context in which firm operate. Christophers' (2013) work on banking and financial services which shows how firm-level practices interact with institutional configurations across a range of different boundaries that transcend both political borders and industries. More recently, Knight \& Wojcik (2016) make an important contribution to theorising the spatiality of certain key corporate practices, linking urban and regional science approaches with those in organisational studies around firm-level 'boundary spanning' practices. In seeking to better understand why investment banks 'move between regions once they have become embedded' (ibid), they focus on how boundary spanners 'help facilitate the exchange of information across boundaries in order to support efficient strategic coupling (ibid.: 656). In particular, the research examines how boundary spanning practices differ according to the characteristics of the information being processed, the perceived environmental uncertainty and the needs of the financial firm. Importantly here, the study demonstrates how different types of these spanning practice are important at different times for the financial firm and why certain practices move between different IFCs.

Third, a body of work has examined what can be broadly framed as innovation and learning practices within the context of professional service. Hall (2008) examines the transnational practices of business education, in particular examining the link between spaces 
of business education and role in shaping and developing the nature of organizational practices within finance and professional services within world cities. Work within the socalled 'new management geography' (c.f. Schlunze et al 2012) has also examined the nature of practices undertaken by hybrid or 'global' managers within the transnational corporate context, in part again concerned with the nature of managerial practice within IFCs and amongst key professional service managers who act as intermediaries for transnationalising firms.

Finally, another strand has examined the blurring of different professional service practices across firm and non-firm organizational boundaries. In investigating this 'porosity' (c.f. Hertog 2000) of professional service firms as actors, the distributed nature of practices across and between firms is revealed in producing economic outcomes. Examples here include work on regional economies in Norway that shows how economic success is a product of cross-firm practices spanning multiple professional service industries such as design, architecture or creative services (Bryon \& Rusten 2005; Rusten et al 2005). The complex spatial configuration of these practices creates a problematic blurring of 'where' the services are delivered (in both locational and organizational terms). Equally, research on the global financial crisis between 2007 and 2009 has examined how despite the popular and policy perception of the investment banks being the key cause of the crisis, the actors that produced this negative outcome are distributed through a range of organizations and industries across a globally-extensive network of locations (Aalbers 2009; Wójcik 2013b). This poses a significant challenge to the way in which professional service activities might be understood as 'discreet' industries with growing evidence also that many professional service firms are increasingly engaged in diverse activities beyond their nominal remit (e.g. law firms providing consultancy services). (cf. Kipping \& Kirkpatrick 2013).

These literatures help inform the basis for the framework for conceptualising professional service practices I want to propose here. The argument is that the literature to date has variously focused on certain key practices and has also partially engaged with the complexity of their spatiality, but there is not thus far an attempt to develop either a more holistic typology of what key professional service practices are evident or resolve the complex spatial form of these identified practices. Figure 1 draws on this literature, along with the research presented in the later part of this paper, to tentatively outlined such a typology. This is not intended to represent an exhaustive framework but rather a starting point for conceptualising some of the key professional service practices that are evident across many knowledge intensive professional service industries. 


\section{[INSERT FIGURE 1 ABOUT HERE]}

To some extent informed by Knight \& Wojcik’s (2016) approach, the typology outlined characterises key professional services by function, practice community and key spatial dimensions. However, it also augments the scope of each of these categories to seek to capture the nature of key practices across a spectrum of professional service industries. This represents the first of two steps in developing a new mid-level theoretical approach to understanding professional service practices within IFCS. We now need to consider the second step in outlining next a theoretical approach for conceptualising these practices in place - and specifically in the context of the IFC or world city as a key host context for these practices.

\subsection{Theorising the Nexus of Professional Service Practice Practices in IFCs}

A key proposition of this paper is that much of the existing cross-disciplinary literature on professional services and IFCS or the WCA has identified at least three significant conceptual issues that need to be addressed: (I) the benefit of a practice-focused approach in unpacking the 'black box' of internal organizational dynamics within the complex nature of IFCs (c.f. Knight \& Woijcik 2016); (II) the need to better conceptualise the conflation of locallyembedded and translocal practices that perforate IFCs and WCAs that cannot be fully capture by concepts of local clusters and global pipelines in relational terms and (III) the currently ambiguous status of the significance of the IFC as a place with localised attributes and institutions versus the strong distanciated interconnectedness of many professional service industries and firms.

In order to seek to push the debate into new theoretical waters, this section proposes a second element to its new conceptual framework that seeks to capture these different dimensions to the nature of IFCs and professional service industries through the idea of a nexus. The nexus as a concept is deployed elsewhere in social science to address similar theoretical challenges of holding constant qualitatively different epistemological dimensions to a phenomenon within the same theoretical framework (Stein et al 2014)). Its purpose is to enable in this case a retheorisation of the IFC that does not theoretically over-prioritise (and risk therefore overdetermining understanding) one of the key dimensions to its contemporary form. A concept of the nexus of professional service practices within IFCs thus permits theorization that centres analysis on how a range of mid-level practices - not restricted to 
specific organizations and not confined as phenomenon to the IFC as a 'local' place - shape the nature of economic outcomes that emerge. This aim is to overcome the limitations of currently deployed concept of the cluster which tends to overprioritise firms with their boundaries and the qualities of the place where a cluster is located over translocal relationships (the ‘bolt-on’ of the concept of a global pipeline notwithstanding).

\section{[INSERT FIGURE 2 ABOUT HERE]}

This framework for theorizing professional service practices as a nexus thus 'holds constant' the scope to analyse the relative powers of different actors, the spatial form of those actors and the significance of near and distant relationships in seeking to understand the most significant factors that shape economic outcomes and which also characterize the key repeated and routinized practices that constitute the nature of a given IFC or WCA. In Schatzki's terms, it creates a level playing field using an analysis of multiple professional services micro- practices (praxis) to theorise key the meso-level practices (practice) that shape IFC development in a manner that is sensitive to the complex spatiality of both, accounting for both the throwntogetherness and perforated nature of IFCs as places that form the context where both forms of practice are enacted.

This moves the concept of the IFCs as a fixed, material 'site of production' (in Sassen's original terms) to a more sophisticated framing as a perforated and dynamic nexus rather than a bounded (albeit relational) node for economic activity. It is an attempt therefore to develop a next step beyond the powerful idea of firms, clusters or actors being locallyembedded but also connected to global pipelines, to understanding how the relational nature of economic action is constituted in place by both local and distant actors at the same time as key practices are enacted.

\section{4) Two distinctive Chinese IFCs: Hong Kong and Beijing}

In order to illustrate how this conceptual framework can be applied, the paper now presents research into the nature of professional service practices in two contrasting Chinese IFCs Hong Kong and Beijing.

Existing research does identify significant distinctive contrasting functions between these two Chinese IFCs. Lai (2012) - in an analysis that also includes Shanghai - argues that the three key Chinese IFCs have different dominant characteristics in relation to their role in 
relation to both the domestic Chinese economy and then international financial system (see also Daniels 2013). In examining IFCs relationally as ‘embedded networks of interdependence (and see Faulconbridge 2004), Lai accounts for the continued pre-eminence of Hong Kong as an IFC in China, in contrast with specific functional roles for Beijing and Shanghai. She argues that Hong Kong acts primarily as an offshore financial centre, with its status as a special autonomous economic area in comparison to Beijing's role as 'political centre’ and Shanghai as a 'business centre’ (see also Li \& Kratke 2016; Pan et al 2016). These forms of distinctiveness are grounded in a mixture of different historical backgrounds, social and cultural milieux and institutional environments (ibid.: 1292) and are seen as complementary to each other. This is based on empirical research on the nature of the offices of foreign banks in each IFC, with representative offices in Beijing and treasury business offices in Hong Kong. Hong Kong's dominance is due to its 'established administrative capability, stability, financial and legal expertise and unique trading opportunities' as a more open economy (ibid.) Institutionally this has a political basis in Article 109 of the Basic Law of Hong Kong (1990) which establishes the commitment to maintain Hong Kong as an IFC. Hong Kong’s distinctive strength cannot be matched by Shanghai because of the regulatory restrictions the latter city is subject to.

The research presented here seeks to build upon but also advance a more nuanced set of insights to these general characteristics of distinctiveness identified by Lai in her earlier study. The data is drawn from a project which sought to investigate the nature of inward investment into the Chinese economy by foreign investors. The research ${ }^{\mathrm{i}}$ examined the nature $^{-}$ of professional service inputs around investment practices Hong Kong and Beijing. It thus represents multi-sector data rather than the narrower focusing on banking. The research sought to follow key actors and their economic practices in these two cities, with depth interviews with key informants spanning at least five professional service industries: investment banking, asset and fund management, property and real estate, legal services and management / strategy consultancy. The respondents were mostly at senior management level within professional service firms, although the interviews also included a number of people at a mid-management operational level within professional service firms and several interviewees who represented clients (rather than professional service providers). More than twenty-five interviews were conducted over an 18 month period between late 2013 and mid 2015, with the project also gathering secondary data sources supplied by interviewees, corporate publications and policy media. The interviews ranged between an hour and two hours in length, and several respondents also undertook a follow-up interview. In a number 
cases, further correspondence was also undertaken via email subsequently to clarify points made.

\subsection{Hong Kong}

The research suggests that Lai's characterization of Hong Kong as acting like an 'offshore' financial centre for China with the PRC is both an evolving state of affairs, and also in need of further development. Deploying an analysis of the nature of professional service practices that are being undertaken across a range of sectors within the IFC, suggests that Hong Kong should not be understood in any simplistic way as an offshore centre, but that it's distinctiveness is based and continue to develop around its transgressive position of being both onshore and offshore in relation to its role as an IFC for the Chinese economy. In this respect, at least four sets of mid-level practices that have different nexus configurations across the dimensions of function, community, spatiality are identifiable from the research.

\section{[INSERT TABLE 1 ABOUT HERE]}

Firstly, respondents pointed to a range of practices that enable Hong Kong to act as this important and distinctive 'gateway' for foreign investment into China. The first row in Table 1 summarises the finding as to the key mid-level practices through the nexus framework that constituent and reproduce this 'gateway' distinctiveness to Hong Kong. The findings suggest that Hong Kong does not simply attract activity because of its advantages around offshore status and less regulation than Shanghai, but also because it is the context for a set of innovative practices that enable effective cross-border investment. In that respect, the offshore / less regulatory environment evidenced in Lai's study is supplemented by a set of specific place-based practices that are not available in Shanghai or Beijing. These reside in the available highly skilled professional service labour market of the city which is grounded in its longstanding history as a financial centre with linkages to western markets, business practices, regulatory norms and ways of working. One Partner in a US consultancy firm articulated this advantage well:

I think the legacy here [Hong Kong] produces a special set of knowledge and skills in several industries - finance, law, consultancy and so on...this is where if you're an investor you come to find out how to do it [invest in 
China], where there's the track-record of working around all the challenges in PRC...firms here have the people and the long experience of doing these kinds of deals, knowing how to go about it in the Chinese context but also being aligned with global norms, with what they think in London or New York or Zurich or wherever...

(Partner, USConsultancy2, Hong Kong)

Second, these mid-level practices exist within and between professional service firms, based around the distinctive labour force of professional service employees present. Hong Kong has a long history of ex-patriate professional service practitioners who are important in this respect. Whilst the relative proportions of so-called 'local' talent is increasing with Chinese-background professional service employees present in ever greater numbers, the business environment within firms and within the Hong Kong business community retains many of the historical cultural facets of this outward expatriate workforce. To some extent these attributes of this professional service practice community derive from the historical 'throwntogetherness' of this labour force in place in terms of Hong Kong's material and social spaces of interaction.

The second row of Table 1 thus summaries the findings around a range of innovative professional service practices associated with this practice community that are to a considerable extent unique to this IFC, and which represent the cutting edge of services that non-Chinese investors can access globally when making and implementing investment decisions. If this distinctive Hong Kong-based practice community is important in generating certain types of strategic and operational practices which provide competitive advantage to the IFC, the research also furthermore identifies the translocal dimensions to the spatiality of these practices that reflect the geographical linkages of both professional service firm offices within the IFC and of the transnationally-connected practice community. One respondent in a fund management firm provided succinct insight into this:

The strategy is devised here, but is reliant on a great deal of overseas knowledge and a live network. It's that mixture of people based here with the expertise and the experience of dealing with the complexity of China, but with knowledge, connections, experience from elsewhere...

(Fund manager, EuroFund3) 
A third set of related mid-level practices relate to what might be termed 'hybrid Chinese / non-Chinese practices' around delivering business deals and their enactment. The practices straddle strategic, operational and knowledge categories. The presence of a large number of non-Chinese firms within the special economic zone means that there is a concentration of professional service firms that have extensive historical experience of facilitating inward investment into China and can tailor their nature of the services needed:

\section{Hong Kong is important as a kind of cross-over place...you have the western expertise, able to deal in global business norms and approaches, but you also have that knowledge of doing this inside the PRC, of the kinds of things you need to do to make it work which are very much local, about local uncertainty and risk...so it's that mix that the client really wants}

(Partner, UK Law firm1)

A good example of this is evident around the mid-level legal service practices coalesced around inward investment project teams composed of both western Hong Kongbased law firms having working with partner domestic Chinese law firms (normally based in offices in Shenzhen). The project ecology (c.f. Grabher 2002) of the corporate legal agreements developed to enable investment deals for non-Chinese companies investing in China has created a distinctive set of practice community capacities centred on Hong Kong that cannot be easily reproduced in other Chinese (or non-Chinese IFCs). Spatially these practices are not confined to Hong Kong insofar as there some aspects of these services are available in other Chinese cities (e.g. Shanghai) and also the nature of the service itself often draws on distanciated relations with actors based elsewhere (for example, advisory practices delivered by those based in London or New York). However, the research suggests overall that proximity is important given the need for professional service providers to be highlyengaged with local knowledge and a fluid and dynamic regulatory environment. It is clear also, as one respondent suggested, that the informal spaces of restaurants, bars and clubs with their cultural milieux plays a contextual role in developing 'innovative cultural business sensitivity’ [Manager, Asset Management Firm2]. In this respect, these practices are most concentrated in Hong Kong as a material and socio-culturally reproduced place that straddles both access to global norms and expertise whilst also being 'close' to the relevant Chinese 
context. As a consequence, locational decisions by investors as to where to undertake investment activity are shaped by this distinctive offer by the IFC:

We base our decision making [here] because of the breadth of western and Chinese expertise, and the legacy of experience ... which is about also who lives and works here more generally, who you can hire, who you go for lunch or a coffee with...

(Partner, USConsultancy2, Hong Kong)

Finally, it is also clear from the research that the distinctiveness of these mid-level practices cannot be simplistically reduced to a practice community or spatial configuration related to one professional service sector. It is not a question of Hong Kong’s legal services sector, for example, being the only locus for innovative professional service mid-level practices, but rather that the distinctive nature of professional service practices in the IFC are distributed across firm and sector boundaries.

The third row in Table 1 summarises the sectoral composition of key practices in relation to the professional service typology proposed earlier. A good example of this is illustrated by one particular very large project deal that several respondents were involved with at the time of the interviews in 2014 from different professional service industries:

\footnotetext{
"The X deal has been challenging because of the minefield of Chinese regulatory issues that there are in these kinds of raw materials industries...we can construct the contracts of course, and circumvent some of the ownership rights issues around assets, but there are specialists advising on the issues the client needs to consider...like what would make the Chinese government block important elements for a start!" [paraphrased] (Asset Manager, USBank3, Hong Kong)
}

Defining the specific industry or 'sector' against common classifications of professional service activity is also difficult in this case as the consultancy advice blurred areas that in western IFCs would be a mix of management consultancy, tax advice (accountancy) and public affairs advice (political consultancy). 


\subsection{Beijing}

Beijing has not historically had a leading role in financial services within China, the economy being long dominated by Shanghai as the major domestic financial centre even prior to the return of Hong Kong at the handover in 1999. However, Beijing has always played a significant domestic role as a financial centre in modern China (c.f. Liu et al 2013) with a particular legacy of head office location over the major national (and nationally-owned) banks and associated professional service associated with their activities (Zhao 2013). It is also the location of the head offices of many large state-owned enterprises. Lai (2012)'s research indicates that as an IFC Beijing 'has attracted foreign investment banks and other financial operations that benefit from proximity and regular interaction in political and regulatory circle’ (ibid.: 1292). This is seen as a complementary role to Shanghai's dominance in financial deals and transactions with each centre's specific role being reproduced with its interdependent relationships with other IFCs' (ibid.: 1292) (see also Li \& Kratke 2016).

The research presented here to some extent sheds light on the complementary of Beijing's role in relation to both Hong Kong and Shanghai but also - whilst not fully contesting the conceptualizations - indicates a more complex set of processes of reproduction around IFC distinctiveness for Beijing that a wider investigation of the nexus of professional service practices reveals. Again at least four sets of mid-level practices that have different nexus configurations across the dimensions of function, community and spatiality are identifiable from the research.

First, whilst the characterisation of Beijing as dominated by practices with political and regulatory functions is justified, the mid-level practices that reproduce this distinctiveness straddle a range of economic and non-economic actors. This produces a distinctive practice community constituted across professional service firms and institutions of government and regulation. The research thus suggests that to understand the nature and significance of these practices for Beijing requires an understanding of how firm and state institutional actors interact in place, rather than seeing economic actors such as firms within industry sectors as engaging with a static set of institutions that exist within the IFC. It identifies a more dynamic and co-dependent set of practices that straddle firm and institution boundaries in the formation of both strategic and operational activity within the IFC. The first row of Table 2 seeks to capture the types of practices identified. 
Second, as with Hong Kong, these mid-level practices also exist within and between professional service firms, based around the distinctive labour force of professional service employees present. However, in contrast to Hong Kong, Beijing does not have a long history of ex-patriate professional service practitioners. Rather, the community is dominated by domestic Chinese professionals, although with a high presence of foreign-educated Chinese professionals. The workforce is thus dominated by a high proportion of 'local talent' within professional services firms much more familiar with the cultural and behavioural expectations of business practices in China's political capital, but also with a growing proportion of employees with both transnational experience and translocal connections. The research thus indicates that many of the mid-level practices identified in the first row of Table 2 are perforated by translocal relationships that are shaping the nature of the economic outcomes being reproduced in place. A good example of this referred to by several respondents is the emergence of a sovereign debt industry over the last decade, related to changes in the nature of Chinese state financing and a relaxation of regulatory norms:

Back then [2007], you would not have seen much [sovereign wealth]. It used to be the same as it had been for some decades largely, senior guys in the main banks dealing in Chinese government debt in a fairly pedestrian way... look now and the whole thing has changed. You have all these funds starting up, all these start-up outfits here [Beijing] who look much more like what you'd find in London or Tokyo...and the interesting thing is this is going on here, not Shanghai, because there are still a lot of challenges... you need to be close to the central bank people and so on... [Fund Manager, US-Chinese Joint Venture, Beijing]

In contrast to the hybrid practices identifiable in Hong Kong, a third set of mid-level practices are identifiable in Beijing around the negotiation of the political - regulatory dimensions to business deals. The second row in Table 2 sets out the findings from the research in this respect.

These practices fall largely within the operational and knowledge categories, rather than the kinds of strategic practices found in Hong Kong. Moreover, and contrary to the widespread framing of these practices around local proximity to regulatory institutions, it is clear that these practices are also bound into translocal relations. This is to some extent 
surprising and complicates dominant conceptions of Beijing's placed-based institutions of political governance and regulations. Whilst regulatory institutions clearly are located within the IFC, the research indicates relational connections in the nature of practices enacted by them. That can be the corporate strategy dictated from an overseas head office for a Chinese head office of a financial firm in Beijing, or the way in which Beijing's regulatory institutions are also connected to international policy frameworks or constraints (e.g. 'global' norms of regulation for financial markets). One respondent provided a good illustration of this:

The office here is at the crossover of local regulation and global factors in all kinds of ways... what we are navigating is the rules laid out here but also related to how things are playing out elsewhere...there may be a precedent [deal] in Shanghai where we're talking to them locally but also mindful of what happened last week in Singapore or Kuala Lumpur with another investor, and how the regulators here are also linked into that. (Senior Asset Manager, European Asset Management Firm3, Beijing)

The outcome of this analysis is not to dismiss the major significance of place-based institutions engaged in regulatory practices within the IFC, but to nuance the view of how such institutions exist in place and how the regulatory and governance practices shown in Table 2 are also to some extent bound into translocal relations.

Finally, and fourth, the political/ regulatory characterisation risks characterising Beijing as an IFC lacking in innovation, rather concentrating on the delivery of the practical strategic and operational activities with political and regulatory institutions (c.f. Lai 2012). The research suggests that innovative practices are a crucial element to the distinctiveness of the IFC, if focused around its regulatory and governance character. The third row in Table 2 summarises the key mid-level practices identified in line with the theoretical framework proposed earlier. In line with previous studies, many of these practices are centred on the close relationship between the large Chinese banks and their government owners / regulators.

These mid-level innovative practices in relation to regulation involve a community that again straddles both economic actors and regulatory institutions. This is not to suggest that these professional service practices are co-produced in any simplistic way - economic actors have the major motivation to innovate in terms of their profit motive. However institutional actors are involved in shaping and influencing how innovative financial deals or approaches to investment are developed through an interaction process in place of engagement with key 
actors within firms. One respondent also explained well how this relational differentiation of Beijing as an IFC was identifiable through the nature of this nexus of practices enacted there:

...so if the plan for the deal is put together here, and we maybe do some or all of the finance in Shanghai...then it's in Beijing where you do the due diligence, work out what pitfalls there might be...are you going to get the government vetoing something, are the regulations going to change in six months...

(Managing Director, Institutional Investment Fund, Hong Kong)

Again the spatiality of these innovative practices is unevenly bound into both translocal relationships and transnational labour mobility practices. The example given above - of the nascent sovereign debt industry in Beijing that has emerged since the late 2000s - also provides a good case study of how a differently configured practice community in place compared to Hong Kong is important in the development and reproduction of this new industry and its associated practices. The overseas educational and life experience of key movers in this new sector (their historical personal mobility), along with their local cultural knowledge and ability to adapt the local political and regulatory practices within the IFC, is an important factor in their capacity to establish new firms. Whilst in part translocal in nature, the mid-level practices contrast significantly with the kinds of hybrid business practice important in the case of Hong Kong in reproducing its gatekeeper role as a IFC.

\section{5) Conclusions}

This paper has sort to significantly further advance the theoretical debate about IFCs and world cities in relational post-network and post-hierarchy conceptions of city-regions in the WCA. By deploying a practice-oriented approach it has sought to develop a new epistemological framing of IFC distinctiveness around the key mid-level practices that (re)produce IFC distinctiveness within different regions and economies. The advantage to such an approach is that it enables a much better understanding of the dynamic factors that lead to IFC distinctiveness, and perhaps more importantly, it provides considerable scope to better understand likely future trajectories for specific IFCs.

The crucial issue is the theoretical capacity this approach generates to move beyond seeing IFCs as possessing static characteristics that are confined to them as material places. 
Relational approaches to the WCA and IFCs have helped to develop this arc of theoretical development but key issues remain. At the heart of this is the difficult conceptual challenge of balancing the significance of what exists and occurs in IFCs or world cities as discrete places, and the fact that what exists and occurs is bound into distant entities and relationships in a myriad of ways that shape specific economic outcomes. Understanding IFCs or world cities as relational captures the existence of those connections but only broadly frames an understanding of how distant relationships perforate the IFC as a place, shaping its development.

The approach of this paper has been to argue that a focus on mid-level professional service practices creates scope to overcome some of these challenges. In proposing a focus on key practices in the key economic sectors within IFCs, the aim is to create a new theoretical cut that can cope with the need to understand the balance of near and distant agency in relation to a given economic outcome or phenomenon in an IFC (but which also accounts for the specific contingent facets of place that shape it). This creates an analytical framework that does not reduce the distinctiveness of a IFC or world city to intrinsic qualities that are either contained in place and related to elsewhere, or a consequence of a 'global' set of relationships in the place of flows that is somehow (but ambiguously) partially-embedded in a 'local' place. The fundamental goal is to overcome the evident challenges that have emerged in understanding how local clusters intersect with global relations through a partially recombined binary (global / local) that is constrained epistemological by these spatial categories. In using professional service practices as an analytical lens these tensions are overcome by providing an epistemological framing that appreciates the significance of the spatiality of social action without over-prioritising its spatiality as a heuristic.

The paper has applied this to two Chinese IFCs in order to illustrate the utility of this approach. The findings build on insight into how Hong Kong as an IFC that behaves like an offshore centre in China but revealing a more complex transgressive 'gateway role as an IFC serving the Chinese economy. They also further develop a more nuanced understanding of how Beijing does fulfil a distinctive regulatory and political centre role but that beneath these obvious forms of comparative advantage there lie important forms of distinctive innovation and local labour market formations. Clearly this research only provides a first step in deploying the professional service practice framework proposed in this paper, and in neither case does it represent a comprehensive or exhaustive theorisation of the distinctiveness of these IFCs. However, what it does hope to achieve is to provide a new and conceptually 
useful way of advancing theories of IFC and world city distinctiveness that pushes the relational direction of thinking within the social sciences into new and fruitful territory.

\section{6) References}

Aalbers, M., 2009. Geographies of the financial crisis. Area, 41(1), pp.34-42.

Amin, A., 2002. Spatialities of globalisation. Environment and planning A, 34(3), pp.385399.

Amin A 2004 Regions unbound: towards a new politics of place Geografiska Annaler 86B 33-44

Ancien, D. (2011) Global city theory and the new urban politics twenty years on: the case for a geohistorical materialist approach to the (new) urban politics of global cities. Urban Studies, 48(12), pp.2473-2493.

Bathelt, H., Malmberg, A. and Maskell, P., 2004. Clusters and knowledge: local buzz, global pipelines and the process of knowledge creation. Progress in human geography, 28(1), pp.31-56.

Bassens, D. \& Van Meetern, M (2016) World cities and the uneven geographies of financialization: Unveiling stratification and hierarchy in the world city archipelago. International Journal of Urban and Regional Research, 40(1), pp.62-81.

Bryson, J. and Daniels, P. (eds.) (2015) The Handbook of Service Business, Edward Elgar. Bryson, J.R. and Rusten, G., 2005. Spatial divisions of expertise: Knowledge intensive business service firms and regional development in Norway. The Service Industries Journal, 25(8), pp.959-977.

Cassis, Y. and Collier, J., 2010. Capitals of Capital: The Rise and Fall of International Financial Centres 1780-2009. Cambridge University Press.

Castells, M., 1996. The rise of the network society: The information age: Economy, society, and culture (Vol. 1). John Wiley \& Sons. [1 ${ }^{\text {st }}$ Edition]

Castells, M., 2001. The power of identity: The information age: Economy, society, and culture (Vol. 2). John Wiley \& Sons. [1 ${ }^{\text {st }}$ Edition]

Celata, F. and Coletti, R., 2014. Place-based strategies or territorial cooperation? Regional development in transnational perspective in Italy. Local Economy, 29(4-5), pp.394-411.

Cetina, K.K., Schatzki, T.R. and Von Savigny, E. eds., 2005. The practice turn in contemporary theory. Routledge.

Christophers, B., 2013. Banking across boundaries: placing finance in capitalism. John Wiley \& Sons. 
Cook, A.C., Faulconbridge, J.R. and Muzio, D., 2012. London's legal elite: recruitment through cultural capital and the reproduction of social exclusivity in City professional service fields. Environment and Planning A, 44(7), pp.1744-1762.

Daniels, P.W. (2012) Service industries at a crossroads: some fragile assumptions and future challenges, the Service Industries Journal, 32(3-4): 619-639.

Daniels, P.W. (2013) The transition to producer services in China: opportunities and obstacles, in A.G.O Yeh and F.F Yang (eds.) Producer Services in China: Economic and Urban development, London: Routledge.

Darling J 2010 A city of sanctuary: the relational re-imagining of Sheffield's asylum politics Transactions of the Institute of British Geographers 35 125-40

Liu, H., Shen, Y.M. and Deng, X.L., 2013. Study on the spatial pattern and structure of financial service industry in Beijing. Human Geography, 5, p.012.

Faulconbridge, J.R. (2004) London and Frankfurt in Europe's evolving financial centre network. Area, 36(3), pp.235-244.

Faulconbridge, J.R. (2006) Stretching tacit knowledge beyond a local fix? Global spaces of learning in advertising professional service firms. Journal of Economic Geography, 6(4), 517-40.

Faulconbridge et al (2007) Faulconbridge, J.R., 2007. Exploring the role of professional associations in collective learning in London and New York's advertising and law professional-service-firm clusters. Environment and Planning A, 39(4), pp.965-984.

Faulconbridge, J. (2008) Managing the transnational law firm: a relational analysis of professional systems, embedded actors and time-space sensitive governance. Economic Geography 84: 185-210

French, S., Leyshon, A. and Thrift, N., 2009. A very geographical crisis: the making and breaking of the 2007-2008 financial crisis. Cambridge Journal of Regions, Economy and Society, 2(2), pp.287-302.

Friedmann, J. (1986), The World City Hypothesis. Development and Change, 17: 69-83. Grabher (2002). The project ecology of advertising: tasks, talents and teams. Regional studies, 36(3), pp.245-262.

Hall, S. (2006) What counts? Exploring the production of quantitative financial narratives in London's corporate finance industry. Journal of Economic Geography, 6(5), 661-78.

Hall, S (2007) Knowledge makes the money go round: conflicts of interest and corporate finance in London’s financial district. Geoforum, 38(4), 710-719. 
Hall, S. (2008) Geographies of business education: MBA programmes, reflexive business schools and the cultural circuit of capital. Transactions of the Institute of British Geographers, 33(1), pp.27-41.

Hall, S., Beaverstock, J.V., Faulconbridge, J.R. and Hewitson, A., 2009. Exploring cultural economies of internationalization: the role of 'iconic individuals' and 'brand leaders' in the globalization of headhunting. Global Networks, 9(3), pp.399-419.

Harvey D 1996 Justice, nature, and the geography of difference. Blackwell, Cambridge MA Hertog, P.D., 2000. Knowledge-intensive business services as co-producers of innovation. International Journal of Innovation Management, 4(04), pp.491-528.

Isaksen, A., 2004. Knowledge-based clusters and urban location: the clustering of software consultancy in Oslo. Urban Studies, 41(5-6), pp.1157-1174.

Jones, A., 2013. "Geographies of production I: Relationality revisited and the 'practice shift’in economic geography." Progress in Human Geography 38, no. 4 (2014): 605-615.

Jones, A \& Murphy, J. (2011) Theorizing practice in economic geography: foundations, challenges, and possibilities. Progress in Human Geography 35, 3: 366-92

Jones, A. \& Search, P. (2009) Proximity and power within investment relationships: The case of the UK private equity industry. Geoforum, 40(5), pp.809-819.

Jones, M., 2009. Phase space: geography, relational thinking, and beyond. Progress in Human Geography, 33(4), pp.487-506.

Keeble, D. and Nachum, L., 2002. Why do business service firms cluster? Small consultancies, clustering and decentralization in London and southern England. Transactions of the Institute of British Geographers, 27(1), pp.67-90.

Knight, E. \& Wojick, D. (2016) Geographical linkages in the financial services industry: a dialogue with organizational studies Regional Studies

Kipping, M. and Kirkpatrick, I., 2013. Alternative pathways of change in professional services firms: The case of management consulting. Journal of Management Studies, 50(5), pp.777-807.

Illeris, S., 1996. The service economy. Oxford: Wiley.

Lai, K., 2012. Differentiated markets: Shanghai, Beijing and Hong Kong in China’s financial centre network. Urban Studies, 49(6), pp.1275-1296.

Li, X., \& Kratke, S., (2016) Shanghai’s Attractiveness and Relational Power within the Chinese Urban Network. The science reports of the Tohoku University. 7th series, Geography, 61(1), pp.1-22. 
Malpass A, Cloke P, Barnett C and Clarke N (2007) Fairtrade urbanism? The politics of place beyond place in the Bristol Fairtrade City Campaign International Journal of Urban and Regional Research 31, 633-45

Massey D 2004 Geographies of responsibility Geografiska Annaler 86 B5-18

Massey, D. (2005) For Space (London; Sage)

Meyer, D.R., 2015. The world cities of Hong Kong and Singapore: Network hubs of global finance. International Journal of Comparative Sociology, 56(3-4), pp.198-231.

Meyer, D.R., 2016. Shenzhen in China's Financial Center Networks. Growth and Change, 47(4), pp.572-595.

Murphy, J., 2011. From place to exile. Transactions of the Institute of British Geographers, 36(4), pp.473-478.

Pan, F., Zhao, S., \& Wojcik, D. (2016) The rise of venture capital centres in China: A spatial and network analysis Geoforum 75: 148-158

Parnreiter, C., 2014. Network or hierarchical relations? A plea for redirecting attention to the control functions of global cities. Tijdschrift voor economische en sociale geografie, 105(4), pp.398-411.

Pierce, J., Martin, D.G. and Murphy, J.T., 2011. Relational place-making: the networked politics of place. Transactions of the Institute of British Geographers, 36(1), pp.54-70.

Rusten, G., Bryson, J.R. and Gammelsæter, H., 2005. Dislocated versus local business service expertise and knowledge: the acquisition of external management consultancy expertise by small and medium-sized enterprises in Norway. Geoforum, 36(4), pp.525-539.

Sassen, S. (1991) The Global City (Princeton: Princeton University Press) [1 ${ }^{\text {st }}$ Edition]

Sassen, S., 2002. Global networks, linked cities. Psychology Press.

Sassen, S. (2006) Cities in a World Economy (3rd edition) (London: Sage).

Schatzki (2002) The site of the social: A philosophical account of the constitution of social life and change. Penn State Press.

Schlunze, R., Plattner, M., Baber, W.W. and Agola, N.O., (2012) Spaces of International Economy and Management: Launching New Perspectives on Management and Geography. In Spaces of International Economy and Management (pp. 3-23). Palgrave Macmillan UK. Sigler, (2013) Relational cities: Doha, Panama City, and Dubai as 21st century entrepôts. Urban Geography, 34(5), pp.612-633.

Stein, C., Barron, J. and Moss, T., 2014. Governance of the nexus: from buzz words to a strategic action perspective. Nexus Network Think Piece Series, Paper, 3. 
Strom, P. (2013) Managing the Japanese Service Industry: Location, Competitiveness and Internationalization. Service Industries and Regions, p.407.

Smith, R.G., 2014. Beyond the global city concept and the myth of 'command and control'. International Journal of Urban and Regional Research, 38(1), pp.98-115.

Taylor, P.J., 2005. Leading world cities: empirical evaluations of urban nodes in multiple networks. Urban Studies, 42(9), pp.1593-1608.

Taylor, P.J., Ni, P., Derudder, B., Hoyler, M., Huang, J. and Witlox, F., 2012. Global urban analysis: A survey of cities in globalization. Routledge.

Taylor, P.J., Derudder, B., Faulconbridge, J., Hoyler, M. and Ni, P., 2014. Advanced producer service firms as strategic networks, global cities as strategic places. Economic Geography, 90(3), pp.267-291.

Timberlake, M., Wei, Y.D., Ma, X. and Hao, J., 2014. Global cities with Chinese characteristics. Cities, 41, pp.162-170.

Walther, O., Schulz, C. and Dörry, S., 2011. Specialised international financial centres and their crisis resilience: The case of Luxembourg. Geographische Zeitschrift, pp.123-142.

Wójcik, D., 2013a. Where governance fails: Advanced business services and the offshore world. Progress in Human Geography, 37(3), pp.330-347.

Wójcik, D., 2013b. The dark side of NY-LON: Financial centres and the global financial crisis. Urban Studies, 50(13), pp.2736-2752.

Wójcik, D., and James C. (2015) "'Capitalist tools in socialist hands’? China Mobile in global financial networks." Transactions of the Institute of British Geographers 40, no. 4 (2015): 464-478.

Wood, P., 2005. A service-informed approach to regional innovation-or adaptation?. The Service Industries Journal, 25(4), pp.429-445.

Zhao, S.X., 2013. Information exchange, headquarters economy and financial centers development: Shanghai, Beijing and Hong Kong. Journal of Contemporary China, 22(84), pp.1006-1027. 
Figure 1 - $\quad$ A Typology of Professional Service Practices

\begin{tabular}{|c|c|c|c|}
\hline Function & Practice Community & $\begin{array}{l}\text { Key Spatial } \\
\text { Dimensions }\end{array}$ & Example \\
\hline Strategic & Firm, investors & $\begin{array}{l}\text { Corporate, IFC, } \\
\text { translocal }\end{array}$ & $\begin{array}{l}\text { Expanding office in } \\
\text { an IFC }\end{array}$ \\
\hline $\begin{array}{l}\text { Organizational } \\
\text { /Operation }\end{array}$ & $\begin{array}{l}\text { Firm, subidiaries, partner } \\
\text { firms }\end{array}$ & $\begin{array}{l}\text { Corporate, IFC, national } \\
\text { / regional }\end{array}$ & $\begin{array}{l}\text { Forming partnership } \\
\text { with 'local firm' }\end{array}$ \\
\hline $\begin{array}{l}\text { Managerial } \\
\text { /Control }\end{array}$ & Firm & $\begin{array}{l}\text { Corporate, IFC, } \\
\text { translocal }\end{array}$ & $\begin{array}{l}\text { Recruiting new staff } \\
\text { to operation }\end{array}$ \\
\hline $\begin{array}{l}\text { Knowledge/ } \\
\text { Learning }\end{array}$ & $\begin{array}{l}\text { Firm, industry, project } \\
\text { groups, profession }\end{array}$ & $\begin{array}{l}\text { IFC, translocal } \\
\text { professional }\end{array}$ & $\begin{array}{l}\text { Developing new } \\
\text { product offer from } \\
\text { project experience }\end{array}$ \\
\hline $\begin{array}{l}\text { External } \\
\text { Institutional / } \\
\text { Regulatory }\end{array}$ & Firm, insitutions, regulators & IFC, national & $\begin{array}{l}\text { Succesfully gaining } \\
\text { right to provide } \\
\text { service with } \\
\text { regulator }\end{array}$ \\
\hline Market & $\begin{array}{l}\text { Firm, client firms, } \\
\text { insitutions }\end{array}$ & IFC, national, regional & $\begin{array}{l}\text { Gaining new client in } \\
\text { IFC }\end{array}$ \\
\hline
\end{tabular}


Figure 2 - The Professional Service Practice Nexus in an IFC (key intersections)

\section{Functions}

Strategic Operational Managerial Knowledge Institutional Market

Practice

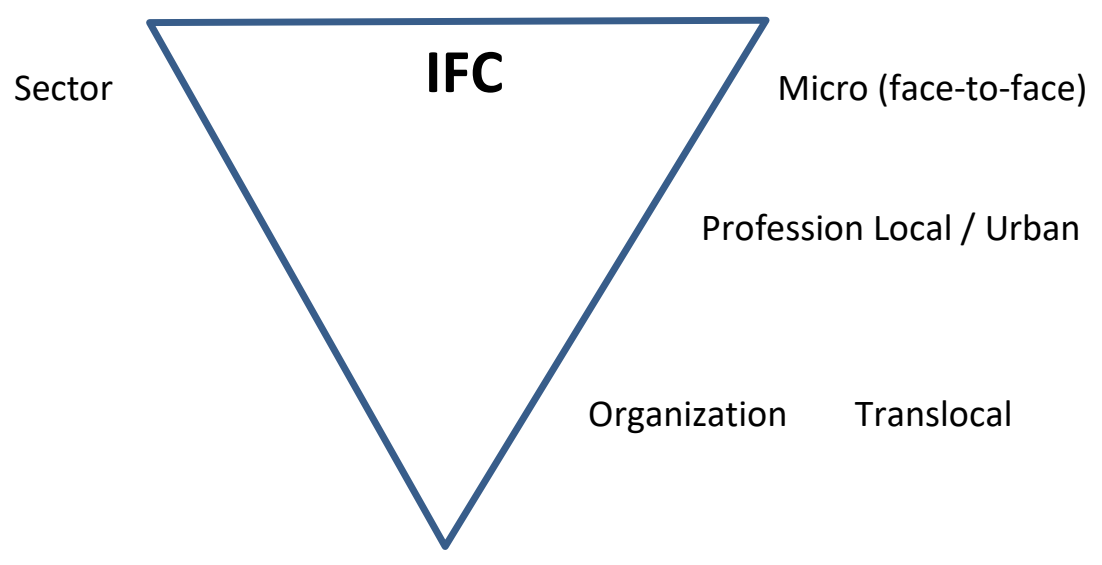

Communities

Spatiality 
Table 1 - Key Mid-Level Professional Service Practices in Hong Kong (from study)

\begin{tabular}{|c|c|c|c|}
\hline & Function & Practice Community & $\begin{array}{l}\text { Key Spatial } \\
\text { Dimensions }\end{array}$ \\
\hline $\begin{array}{l}\text { Gateway } \\
\text { Practices }\end{array}$ & $\begin{array}{l}\text { Chinese deal creation } \\
\text { Corporate translation / } \\
\text { contextualisation } \\
\text { External investor alignment } \\
\text { Client introduction }\end{array}$ & $\begin{array}{l}\text { Firm, client } \\
\text { Firm } \\
\text { Firm, global investors } \\
\text { Firm, client, profession }\end{array}$ & $\begin{array}{l}\text { Corporate, IFC, } \\
\text { national / regional } \\
\text { Corporate, IFC, } \\
\text { national / regional } \\
\text { Corporate, translocal } \\
\text { Corporate, IFC, } \\
\text { translocal }\end{array}$ \\
\hline $\begin{array}{l}\text { Innovation } \\
\text { Practices }\end{array}$ & $\begin{array}{l}\text { Regulatory compliance } \\
\text { Tailored product creation } \\
\text { Special investment vehicles } \\
\text { Market making }\end{array}$ & $\begin{array}{l}\text { Profession, institutions } \\
\text { Firm, client } \\
\text { Profession, investors, } \\
\text { institutions } \\
\text { Firm, client, institutions }\end{array}$ & $\begin{array}{l}\text { Corporate, IFC, } \\
\text { national / regional } \\
\text { Corproate, IFC, } \\
\text { translocal } \\
\text { IFC, national / regional, } \\
\text { translocal } \\
\text { IFC, national, regional }\end{array}$ \\
\hline $\begin{array}{l}\text { Hybrid } \\
\text { Chinese / } \\
\text { Non-Chinese } \\
\text { Practices }\end{array}$ & $\begin{array}{l}\text { Joint project working } \\
\text { Deal negotation } \\
\text { Due diligence }\end{array}$ & $\begin{array}{l}\text { Firm, client, profession } \\
\text { Firm, client } \\
\text { Profession, firm }\end{array}$ & $\begin{array}{l}\text { IFC, regional } \\
\text { Corporate, translocal } \\
\text { Corporate, IFC }\end{array}$ \\
\hline
\end{tabular}

Source: Author interviews and secondary sources 
Table 2 - Key Mid-Level Professional Service Practices in Beijing (from study)

\begin{tabular}{|c|c|c|c|}
\hline & Function & Practice Community & Key Spatial Dimensions \\
\hline $\begin{array}{l}\text { Regulatory } \\
\text { Practices }\end{array}$ & $\begin{array}{l}\text { Strategic investment in } \\
\text { China } \\
\text { Negotations of in-country } \\
\text { business adaptation } \\
\text { Risk management } \\
\text { Local compliance }\end{array}$ & $\begin{array}{l}\text { Institutions, firms, } \\
\text { profession } \\
\text { Institutions, firms, } \\
\text { profession } \\
\text { Firm, global investors } \\
\text { Institutions, firms, } \\
\text { professions }\end{array}$ & $\begin{array}{l}\text { IFC, national } \\
\text { IFC, national } \\
\text { Corporate, translocal } \\
\text { Corporate, IFC, translocal }\end{array}$ \\
\hline $\begin{array}{l}\text { 'Local talent' } \\
\text { Practices }\end{array}$ & $\begin{array}{l}\text { Translation of global } \\
\text { busienss norms } \\
\text { Tailored product creation } \\
\text { Negotation in grey } \\
\text { regulatory context }\end{array}$ & $\begin{array}{l}\text { Profession, institutions, } \\
\text { firms } \\
\text { Profession, firms, } \\
\text { institutions, clients } \\
\text { Institutions, profession, } \\
\text { firms }\end{array}$ & $\begin{array}{l}\text { Corporate, IFC, national } \\
\text { Corproate, IFC, translocal } \\
\text { IFC, national }\end{array}$ \\
\hline $\begin{array}{l}\text { Deal-context } \\
\text { Practices }\end{array}$ & $\begin{array}{l}\text { Deal facilitation } \\
\text { Deal negotation with local } \\
\text { institutions }\end{array}$ & $\begin{array}{l}\text { Firm, client, profession } \\
\text { Institution, firm, profession }\end{array}$ & $\begin{array}{l}\text { IFC, regional } \\
\text { IFC, corporate, translocal }\end{array}$ \\
\hline $\begin{array}{l}\text { Innovation } \\
\text { Practices }\end{array}$ & $\begin{array}{l}\text { Market making (state } \\
\text { intermediated) } \\
\text { New financing forms } \\
\text { Industry creation }\end{array}$ & $\begin{array}{l}\text { Profession, firms, } \\
\text { institutions } \\
\text { Firms, profession } \\
\text { Profession, clients }\end{array}$ & $\begin{array}{l}\text { IFC, national } \\
\text { IFC, national, corporate, } \\
\text { translocal } \\
\text { IFC, national, translocal }\end{array}$ \\
\hline
\end{tabular}

Source: Author interviews and secondary sources 
'The research project was funded by the British Academy. 